\title{
COVID-19 and Dentistry-A Perspective
}

\author{
Mithra N Hegde ${ }^{1 *}$ Shazeena Qaiser ${ }^{2}$, Nidarsh Hegde ${ }^{3}$
}

${ }^{1}$ Vice Dean and Head of the Department, Department of Conservative Dentistry \& Endodontics, A B Shetty Memorial Institute of Dental Sciences, NITTE University, Mangalore, Karnataka, India.

${ }^{2}$ Post Graduate Student, Department of Conservative Dentistry and Endodontics, A B Shetty Memorial Institute of Dental Sciences, NITTE University, Mangalore, Karnataka, India.

${ }^{3}$ Principal, J N Institute of Dental Sciences, Manipur, India.

*Corresponding Author: Mithra N Hegde, Vice Dean and Head of the Department, Department of Conservative Dentistry \& Endodontics, A B Shetty Memorial Institute of Dental Sciences, NITTE University, Mangalore, Karnataka, India; Tel: +91-9845284411; Email: hod.cons.absmids@nitte.edu.in; drhegdedentist@gmail.com

Received Date: 01-05-2020; Accepted Date: 09-05-2020; Published Date: 18-05-2020

Copyright $^{\oplus} 2020$ by Hegde MN, et al. All rights reserved. This is an open access article distributed under the terms of the Creative Commons Attribution License, which permits unrestricted use, distribution, and reproduction in any medium, provided the original author and source are credited.

\begin{abstract}
The novel Coronavirus (nCoV-19) pandemic that originated in Wuhan, China, has become a major public health challenge all around the world. Due to the inherent transmission characteristics of the virus, i.e., through droplet infection or airborne, dental professionals are at a higher risk of exposure. This review gives a preliminary insight into the disease spread and highlights the crucial elements to be considered in terms of recommendations, guidelines, preventive measures, patient management protocol, current medications, and pipeline drugs.
\end{abstract}

\section{Keywords}

COVID-19; Coronaviruses; Severe Acute Respiratory Syndrome (SARS) Coronavirus; Dental Clinics; Infection Control; Transmission; Hydroxychloroquine; Chloroquine; Remdesivir

\section{Introduction}

The novel coronavirus (SARS-CoV-2 [2019-nCoV]) belongs to the family of RNA viruses in the Nidovirales order [1]. It is named for its crown-like shape under a microscope ("corona"

Hegde MN | Volume 1; Issue 1 (2020) | JDHOR-1(1)-003 | Review Article

Citation: Hegde MN, et al. COVID-19 and Dentistry-A Perspective. J Dental Health Oral Res.

2020;1(1):1-12.

DOI: http://dx.doi.org/10.46889/JDHOR.2020.1103 
comes from the Latin word for "crown" and the Ancient Greek korōnè, meaning garland, or wreath). Coronavirus disease was first described in 1931, with the first coronavirus (HCoV229E, HCoV-0C43) isolated from humans in 1965 [2]. Since then, various other subtypes have been identified like SARS-CoV in 2003, HCoV NL63 in 2004, HKU1 in 2005, MERS-CoV in 2012, and now SARS-CoV-2 (formerly known as 2019-nCoV) in 2019. These have been the cause of three large-scale pandemics in the last two decades: SARS, MERS, and the current 2019-nCoV [3]. With the first outbreak initiated in Wuhan, China in November 2019, this disease has spread rapidly all around the world and was officially acknowledged by WHO as a pandemic with almost 3,260,000 infected cases and 2,33,000 deaths globally up to May 1, 2020 [4].

Due to the unique characteristic of a dental healthcare setting, the dental practitioner/dental personnel, as well as the patients, are at considerable risk of cross-infection. This makes it necessary to have a complete understanding of effective infection-prevention protocols for the patients and the clinicians.

The purpose of this review is to provide a critical understanding of COVID-19 in terms of the associated risk factors, management strategies, including general and dental, and the emerging potential treatments.

\section{Evidence Acquisition}

This comprehensive review was conducted using the MEDLINE/PubMed, Scopus, Google Scholar and Cochrane Databases. Also, the information was also obtained from the following international surveillance agencies: World Health Organization (WHO), US Centers for Disease Control and Prevention (CDC). Databases were searched from April 2019 up to April 2020 using a search strategy. The MeSH terms were used including 'COVID-19'or 'Coronavirus' or '2019-nCoV', 'transmission of 2019-nCoV in dental clinics', 'dentistry and 2019-nCoV', 'Prevention of 2019-nCoV'.

Preliminary screening comprised a total of 94 articles, out of which 22 were selected based on the inclusion criteria.-articles in English, published in an indexed journal, on 2019-nCoV, and concerning dentistry. Duplicate articles, non-English studies, and letters to the editor with no references were excluded. It is to be noted that both published and unpublished (pre-print or even pre-proof accepted) were included. After all the screening, the material required for dental health care providers about COVID-19 was extracted from these articles. 


\section{Results}

Risk Factors in Dental Operatory: The dental operatory is the most common site which carries the risk of infection due to the routine dental procedures, whereby the following factors need to be considered [5].

1. Inhalation of Airborne Viral Particles: Once airborne, the virus particles remain suspended for long periods, which in turn allows easy transport to other locations. The transmission may be direct (contact with blood, oral fluids, nasal droplets by coughing, sneezing, talking) or indirect (contaminated instruments and environmental surfaces) (Fig. 1,2) [5].

2. Droplet and Aerosol Transmission: The use of high-energy dental equipment generates moisture droplets and debris usually $5 \mu$ or less in diameter more commonly known as aerosols, which are small enough to stay airborne for an extended period before they get lodged on environmental surfaces or invade the respiratory tract (Disease transmitted: Pneumonic plague, influenza, Legionnaire's disease and Severe Acute Respiratory Syndrome). Conversely, the word 'splatter' is defined as a particle with a diameter of more than $5 \mu$, thus unable to stay in the air. (Disease transmitted: measles, herpes, and SARS). Both are a threat to the infection spread; however, former being the more harmful. The SARS-CoV-2 virus can be detected in aerosols for as long as 3 hours post-treatment, and most importantly, can remain on certain surfaces for prolonged periods (Fig. 1) [6].

\begin{tabular}{|l|l|} 
Surface & Duration \\
\hline Copper & 4 hours \\
\hline Cardboard & 24 hours \\
\hline Plastic & 72 hours \\
\hline Stainless Steel & $2-3$ days \\
\hline
\end{tabular}

Figure 1: Duration of the persistence of coronavirus on inanimate surfaces.

3. Transmission during Asymptomatic Incubation: Owing to the contagious nature of the disease, an asymptomatic patient may also act as a potent source of infection [5].

4. Nosocomial Transmission: According to a recent survey on an analysis of hospitalized patients with SARS-CoV-2, it was presupposed that $41 \%$ patients had acquired the infection in the hospital, out of which health care workers constituted $29 \%$, and patients accounted for only about $12 \%$, thus indicating that the elevated risk of nosocomial transmission [7].

Hegde MN | Volume 1; Issue 1 (2020) | JDHOR-1(1)-003 | Review Article 


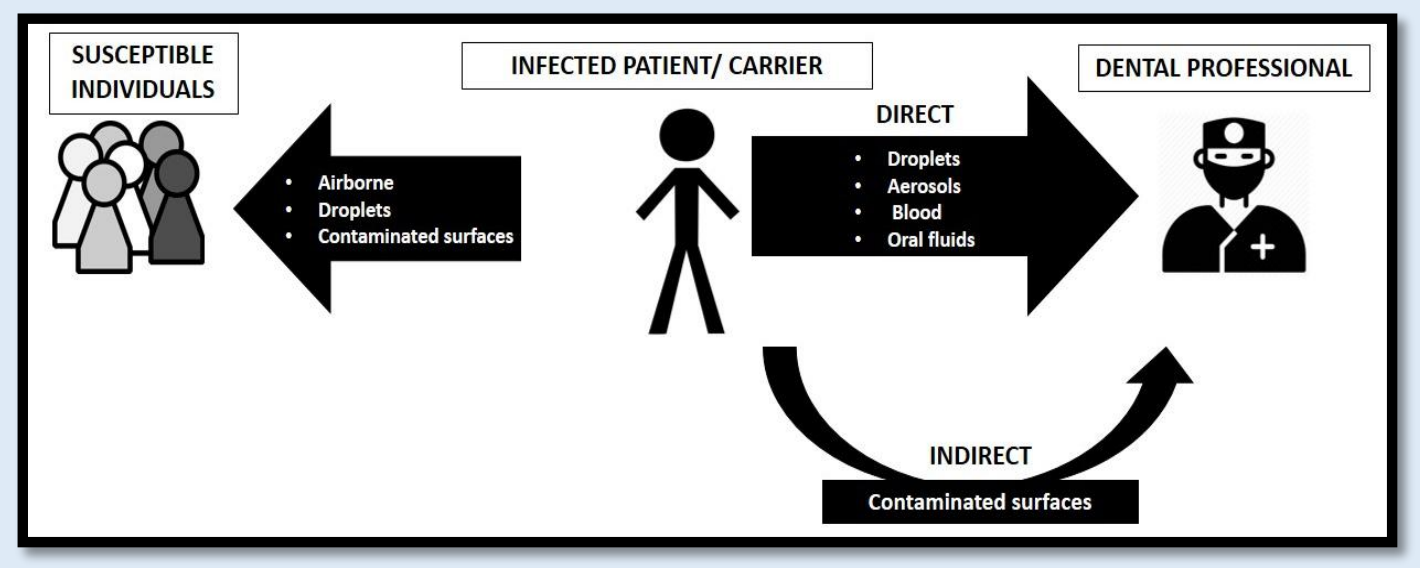

Figure 2: Routes of transmission of 2019-nCoV in dental practice.

\section{Preventive Strategies}

General precautionary measures, as well as specific preventive strategies to be followed in a dental operatory to prevent the transmission of infection, are described below.

\section{General Recommendations}

1. Personal Protective Equipment (PPE): Personal protective equipment, also referred to as $\mathrm{PPE}$, is the equipment worn to minimize the exposure to hazards that would cause serious workplace illnesses. Following are some of them used by health care workers as a part of an effect to protect themselves [8].

1. Head Protection: Disposable working head cap

2. Eye Protection: Protective goggles

3. Facial Protection

- Face shield

- Facemask

- Respirator /N95 respirators

- Offer a higher level of protection

- Preferred for an aerosol-generating procedure

- Triple-layered surgical mask

- FFP2/ FFP3-standard mask

- Hand Protection: Disposable latex gloves/ nitrile gloves

- Foot Protection: Safety boots and shoes

- Others: Long-sleeved Gowns

2. Hand Hygiene Practices: Personal hygiene is an important protection against COVID-19 that most importantly includes frequent hand-washing [9]. Some of the products used are: 
- Soap and water:

- If hands are not visibly soiled

- Alcohol-based hand rubs:

○ Isopropyl, ethyl n-propanol; 60-95\% vol/vol; for $20 \mathrm{sec}$

If hands visibly dirty/ soiled

- Faster and effective

- Performed:

- Before oral examination

- Before any procedure

- Gloves torn during the procedure

- After removing gloves

- After touching the patient

- After touching surroundings or equipment that are not disinfected

\section{Recommendations in Dental Operatory}

In addition to the general precautions, the sequential measures for the prevention of the disease spread in dental healthcare settings are tabulated in Fig. 3 [10].

\begin{tabular}{|c|c|c|}
\hline $\begin{array}{l}\text { 1. TELESCREENING AND } \\
\text { TRIAGING }\end{array}$ & $\begin{array}{l}\text { 2. PATIENT EVALUATION } \\
\text { AND COHORTING }\end{array}$ & $\begin{array}{l}\text { 3. PHARMACOLOGICAL } \\
\text { TREATMENT }\end{array}$ \\
\hline $\begin{array}{l}\text { Preliminary Screening } \\
\text { and triaging through } \\
\text { phone to reduce the } \\
\text { number of direct walk- } \\
\text { ins }\end{array}$ & $\begin{array}{l}\text { Once in dental } \\
\text { operatory, completion } \\
\text { of : } \\
\text { - Medical History } \\
\text { form } \\
\text { COVID-19 } \\
\text { Screening } \\
\text { Questionnaire } \\
\text { True Emergency } \\
\text { Questionnaire } \\
\text { Assessment }\end{array}$ & $\begin{array}{l}\text { For urgent care for } \\
\text { pain/swelling of COVID- } \\
19 \text { suspected/ } \\
\text { confirmed cases: } \\
\text { - Antibiotics } \\
\text { - Analgesics }\end{array}$ \\
\hline $\begin{array}{l}\text { Analysis of: } \\
\text { Exposure to } \\
\text { suspected } \\
\text { /confirmed } \\
\text { COVID-19 patients } \\
\text { - Records of recent } \\
\text { travel history } \\
\text { - } \\
\text { Respiratory } \\
\text { Symptoms }\end{array}$ & $\begin{array}{l}\checkmark \text { Examination: } \\
\text { Temperature } \\
\text { Screening using } \\
\text { Non-Contact } \\
\text { Forehead } \\
\text { Thermometer: } \\
\text { Fever }+(>100.4 \mathrm{~F}) \\
\text { - } \\
\text { Respiratory } \\
\text { Symptoms }\end{array}$ & $\begin{array}{l}\text { Acetaminophen: } \\
\text { preferred for analgesia } \\
\text { rather than ibuprofen in } \\
\text { treating COVID-19 infected } \\
\text { patients, since the latter } \\
\text { may interfere with } \\
\text { immune function. }{ }^{12}\end{array}$ \\
\hline
\end{tabular}

Treatment delayed till 3 weeks *except in cases of emergency care

Figure 3: Stepwise approach to COVID-19 prevention in a dental setting.

Hegde MN | Volume 1; Issue 1 (2020) | JDHOR-1(1)-003 | Review Article 


\section{Dental Treatment Protocol}

Before any treatment, dental personnel must have a thorough awareness of:

- Patient's recent travel history

- Incubation period of the disease

- Isolation protocol of dental procedure

- Disposal of used instruments

A thorough understanding of the difference between an emergency and an elective procedure can help limit the amount of spread of the infection. The ADA provided its members and their patients' detailed guidance about what to consider dental emergencies and nonemergency dental care in order to control the disease spread (Fig. 4) [11]. According to ADA, all the elective procedures need to be postponed for three weeks [12]. However, in case of urgent care such as tooth pain and/or swelling, pharmacological management (antibiotics and/or analgesics) can be helpful until the time of delivery of dental care.

\begin{tabular}{|c|c|c|}
\hline DENTAL EMERGENCIES & DENTAL URGENCIES & $\begin{array}{l}\text { NON-URGENT DENTAL TREATMENTS } \\
\text { (that can be postponed) }\end{array}$ \\
\hline Uncontrolled bleeding & $\begin{array}{l}\text { Severe dental pain from pulpal } \\
\text { inflammation }\end{array}$ & $\begin{array}{l}\text { Initial/periodic oral examinations, recall } \\
\text { visits (Inc. routine radiographs) }\end{array}$ \\
\hline Cellulitis & Pericoronitis / third-molar pain & $\begin{array}{l}\text { Routine dental cleaning ; preventive } \\
\text { therapies }\end{array}$ \\
\hline \multirow[t]{6}{*}{$\begin{array}{l}\text { Trauma involving facial } \\
\text { bones }\end{array}$} & Surgical post-operative osteitis & $\begin{array}{l}\text { Orthodontic procedures other than those } \\
\text { to address acute issues (e.g. pain, } \\
\text { infection, trauma) or other issues } \\
\text { critically necessary to prevent harm to } \\
\text { the patient }\end{array}$ \\
\hline & Abscess & Extraction of asymptomatic teeth \\
\hline & $\begin{array}{l}\text { Tooth fracture resulting in pain or } \\
\text { causing soft tissue trauma }\end{array}$ & $\begin{array}{l}\text { Restorative dentistry including treatment } \\
\text { of asymptomatic carious lesions }\end{array}$ \\
\hline & Dental trauma with avulsion/ luxation & Aesthetic dental procedure \\
\hline & $\begin{array}{l}\text { Final crown/bridge cementation } \\
\text { (if the temporary restoration is lost, } \\
\text { broken or causing gingival irritation) }\end{array}$ & \\
\hline & Biopsy of abnormal tissue & \\
\hline
\end{tabular}

Figure 4: Categorisation of dental conditions based on the degree of emergency.

Following are specific strategies to be followed in case of an emergency dental care:

1. For diagnostic evaluation, extra-oral imaging like CBCT is preferred since conventional radiographic techniques result in excessive salivary secretion and may induce coughing as well. However, if not possible at all, use a double barrier sleeve for intraoral radiographs [13].

Hegde MN | Volume 1; Issue 1 (2020) | JDHOR-1(1)-003 | Review Article 
2. Disposable devices like mouth mirrors, explorers, syringes to be used to prevent crossinfection.

3. Pre-procedural mouth rinse: containing oxidative agents such as $1 \%$ hydrogen peroxide or $0.2 \%$ povidone-iodine have the potential to lessen the salivary microbial load, including SARSCoV [14].

4. The aerosol generation should be minimized $[15,16]$.

- Reducing the use of ultrasonics

- Minimize use of high-speed handpieces

- Avoid three-way syringes

- Chemo-mechanical caries excavation - Carisolv+ spoon excavator or slow speed micromotor handpiece without water spray [7]

5. In an unavoidable aerosol-generating procedure:

- Use of Rubber dam: minimize the production of saliva, blood-contaminated aerosol, splatter of microbial content [15]

- High / low volume saliva ejectors used

- Anti-retraction hand piece: prevents the backflow of oral microbe into tubes of handpiece /dental unit [5]

6. Pulp Extirpation: [7]

- Once opened, irrigation with $5 \% \mathrm{NaOCl}$ is suggested

- Flush the pulp chamber for 5 minutes to achieve hemostasis

- Pulpitis: pulp chamber dried with a steroid containing dressing material

- Symptomatic apical periodontitis: dress with non-setting $\mathrm{Ca}(\mathrm{OH})_{2}$ followed by a more resistant material such as a core build-up glass ionomer material (e.g., Chemfil Rock, Fuji IX, RivaHV) or IRM

7. Suspected or confirmed COVID-19 cases: to be referred to the isolation ward; to be kept in Negative pressure treatment room/Airborne Infection Isolation Rooms (AIIRs) [7].

8. Sterilisation/Disinfection [15,17].

- Autoclave the hand-pieces

○ Temperature $-121^{\circ} \mathrm{C}$

- Saturated steam under at least 15 psi of pressure

○ Duration -for at least 30 minutes

- Reusable instruments should be pre-treated, cleaned, sterilized after each patient

- Ultrasonic Cleaner / Instrument washer

- Use of Cassettes

- Disinfection of inanimate surfaces ( including public areas frequently-door handles, chairs, bathroom

- Effective disinfectants used for 1 minute

Hegde MN | Volume 1; Issue 1 (2020) | JDHOR-1(1)-003 | Review Article 
○ $62 \%-71 \%$ ethanol

○ $0.5 \%$ hydrogen peroxide

- $0.1 \%$ sodium hypochlorite

○ $0.05 \%-0.2 \%$ benzalkonium chloride/ $0.02 \%$ chlorhexidine di-gluconate less effective

- Maintain a dry environment

- Fumigation and ventilation of dental operatory rooms

- Install physical barriers at reception areas

9. Waste Management [18].

- Keep separate color-coded bins/containers to allow segregation of waste

- Double-layer yellow color medical waste package bags and "gooseneck" used

- Use a dedicated collection bin labelled as "COVID-19."

10. Resolved COVID-19 cases seen: [19].

- At least 3 days since symptoms resolved

- At least 7 days since their symptoms first appeared

\section{Treatment}

Presently, no specific therapies have been approved by the U.S. Food and Drug Administration (USFDA) for COVID-19. However, various agents are under investigation and being used for clinical trials (Fig. 5) [20]. Some of them are discussed below.

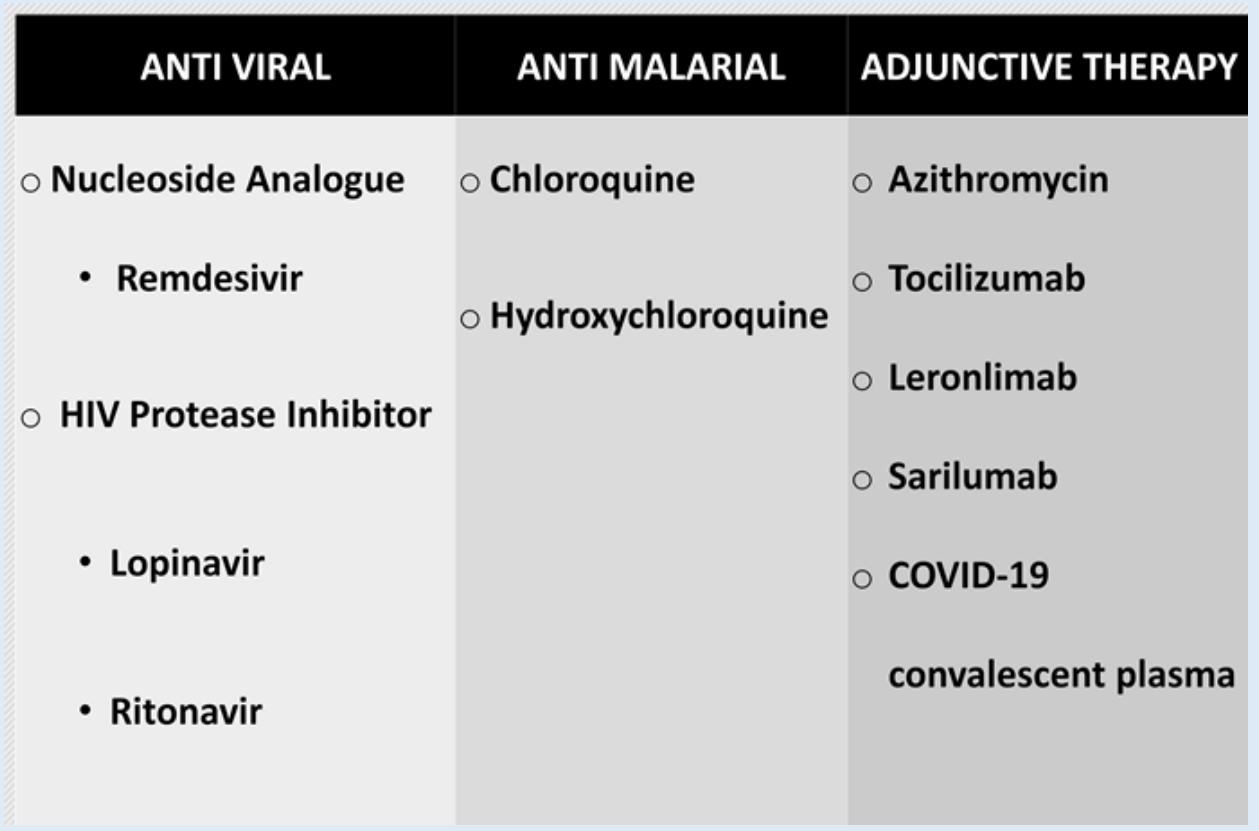

Figure 5: Potential pharmacological agents for treatment of COVID-19. 


\section{Anti-Viral}

- Nucleoside Analogue: Remdesivir

- Broad-spectrum antiviral with a strong in vitro activity against COVID-19

- Mechanism of Action: Inhibits RNA-dependent RNA polymerases (RdRps)

○ Evidence:

- Administered to a hundred confirmed cases in the U.S., Europe, Japan

- Preclinical trials:

- In vitro studies: intense antiviral activity against SARS-CoV-2

- Prophylactic, therapeutic efficacy against 2002 SARS-CoV in a mouse model

- HIV Protease Inhibitor: Lopinavir; Ritonavir:

- Mechanism of Action:

○ Links to Mpro, primary enzyme for coronavirus replication

○ Evidence:

- Preclinical trials: potential activity for other coronaviruses (SARS-CoV and MERS$\mathrm{CoV})$.

- Randomized, controlled trial -199 confirmed COVID 19 cases treated with Lopinavir; Ritonavir

- Not related to a variation from standard of care in the time to clinical improvement

- No significant difference in the mortality between groups at 28 days (19.2\% vs. 25\%)

2. Anti-Malarial

- Chloroquine and Hydrochlorquinone

- Mechanism of Action:

- Inhibition of viral enzymes/ processes

- ACE2 cellular receptor inhibition

○ Immunomodulation of cytokine release

○ Evidence:

- Preclinical trials:

- Both have activity against SARS-CoV-2

- Reports: Chloroquine significantly suppresses the exacerbation of pneumonia patients with SARS-CoV-2 infection

- Hydroxychloroquine more potent than chloroquine

- Non-randomized clinical trial: hydroxychloroquine treatment $(n=26)$ vs untreated negative control

- $70 \%$ of hydroxychloroquine-treated patients cured compared to $12.5 \%$ in untreated control group

- Randomized trial in non-severe COVID-19 $(n=62)$ hydroxychloroquine (I) vs standard treatment (II)

- Fever recovery time shortened in I (2.2 days) vs. II (3.2 days)

- Cough recovery time shortened in I (2 days) vs. II (3.1 days)

- Safety Concerns: 
○ Risk of cardiac arrhythmias (eg. QT prolongation)

- Risk of retinal damage

○ Significant drug interactions

Some of the clinical trials based on the above-mentioned agents have been tabulated in Fig. 6 [21].

\begin{tabular}{|c|c|c|c|c|}
\hline NCT Number & Title & Interventions & Phases & Study Type \\
\hline 1.NCT04320511 & $\begin{array}{l}\text { Hydroxychloroquine Post } \\
\text { Exposure Prophylaxis for } \\
\text { Coronavirus Disease } \\
\text { (COVID-19) }\end{array}$ & Hydroxychloroquine & $\begin{array}{l}\text { Phase 2/ } \\
\text { Phase } 3\end{array}$ & Interventional \\
\hline 2. NCT04325672 & $\begin{array}{l}\text { Convalescent Plasma to } \\
\text { Limit Coronavirus } \\
\text { Associated Complications }\end{array}$ & Convalescent Plasma & Phase 2 & Interventional \\
\hline 3. NCT04292899 & $\begin{array}{l}\text { Study to Evaluate the } \\
\text { Safety and Antiviral } \\
\text { Activity of Remdesivir } \\
\text { (GS-5734â,, C) in } \\
\text { Participants with Severe } \\
\text { Coronavirus Disease } \\
\text { (COVID-19 }\end{array}$ & Remdesivir & Phase 3 & Interventional \\
\hline 4. NCT0428070 & $\begin{array}{l}\text { Adaptive COVID-19 } \\
\text { Treatment Trial (ACTT) }\end{array}$ & Remdesivir & Phase 3 & Interventional \\
\hline 5. NCT04308668 & $\begin{array}{l}\text { Post-exposure } \\
\text { Prophylaxis / Preemptive } \\
\text { Therapy for SARS- } \\
\text { Coronavirus-2 }\end{array}$ & Hydroxychloroquine & Phase 3 & Interventional \\
\hline
\end{tabular}

Figure 6: List of clinical trials on coronavirus registered in the United States.

\section{Future Scope}

According to the Infectious Disease Hub report 2020, a phase I study is being conducted on a potential vaccine, mRNA-1273, and a preclinical, protein-based vaccine candidate, COVID19 S-Trimer, against COVID-19 [22]. The latest report says that $h r s A C E 2$, human recombinant enzyme blocker SARS-Cov-2 turns down viral load in human tissue. Recently, researchers from the University of Pittsburg developed a possible COVID-19 vaccine candidate named PittCoVacc $[23,24]$. There have been multiple similar attempts, but all of this requires testing and funding. Moreover, clinical studies regarding the use of coconut oil and its derivatives are being carried out on COVID-19 infected patients since coconut comprises around 50\% lauric acid, which is reported to have a potent virucidal effect through the disruption of the lipid membrane of the virus. This is one major reason behind advocating the use of soap (sodium

Hegde MN | Volume 1; Issue 1 (2020) | JDHOR-1(1)-003 | Review Article 
laureate) and water against the disease spread [25,26]. Other investigations are still going on, which include the use of melatonin, lactoferrin, as potential agents against the disease based on further experiments to confirm [27,28].

\section{Conclusions}

Healthcare professionals, including dental healthcare providers, have to keep up the standards of infection prevention and control. Appropriate precautionary measures taken in a dental setting can significantly reduce transmission and further spread of nCoV-19 infection. It is imperative to make informed clinical decisions, create awareness among the public to avert panic while promoting the health and wellness of our patients during these challenging times.

\section{References}

1. Zhu N, Zhang D, Wang W, Li X, Yang B, Song J, et al. A novel coronavirus from patients with pneumonia in China 2019. N Engl J Med. 2020.

2. Tyrrell Da, Bynoe Ml. Cultivation of a novel type of common-cold virus in organ cultures. BMJ. 1965;1(5448):1467-70.

3. Adhikari SP, Meng S, Wu YJ, Mao YP, Ye RX, Wang QZ, et al. Epidemiology, causes, clinical manifestation and diagnosis, prevention and control of coronavirus disease (COVID-19) during the early outbreak period: a scoping review. Infect Dis Poverty. 2020;9(1):1-12.

4. Coronavirus COVID-19 Global Cases by the Center for Systems Science and Engineering (CSSE) at Johns Hopkins University (JHU). ArcGIS. Johns Hopkins CSSE. 2020.

5. Peng X, Xu X, Li Y, Cheng L, Zhou X, Ren B. Transmission routes of 2019-nCoV and controls in dental practice. Int J of Oral Sci. 2020;12(1):1-16.

6. Van Doremalen N, Bushmaker T, Morris D, Holbrook M, Gamble A, Williamson B, et al. Aerosol and Surface Stability of SARS-CoV-2 as Compared with SARS-CoV-1. N Engl J Med. 2020;382(16):15647.

7. Meng L, Hua F, Bian Z. Coronavirus Disease 2019 (COVID-19): Emerging and future challenges for Dental and Oral. J Dent Res. 2020;99(5):481-7.

8. https://apps.who.int/iris/bitstream/handle/10665/331498/WHO-2019-nCoV-IPCPPE_use-2020.2eng.pdf [Last accessed on 07 May 2020].

9. https://www.who.int/gpsc/5may/Hand_Hygiene_Why_How_and_When_Brochure.pdf [Last accessed on 07 May 2020].

10. Ather A, Patel B, Ruparel N, Diogenes A, Hargreaves K. Coronavirus Disease 19 (COVID-19): Implications for Clinical Dental Care. JOE. 2020.

Hegde MN | Volume 1; Issue 1 (2020) | JDHOR-1(1)-003 | Review Article 
11. https://www.ada.org/en/publications/ada-news/2020-archive/march/ada-develops-guidance-on-dentalemergency-nonemergency-care [Last accessed on 07 May 2020].

12. https://www.ada.org/en/press-room/news-releases/2020-archives/march/ada-calls-upon-dentists-topostpone-elective-procedures [Last accessed on 07 May 2020].

13. Hokett SD, Honey JR, Ruiz F, Baisden MK, Hoen MM. Assessing the effectiveness of direct digital radiography barrier sheaths and finger cots. J Am Dent Assoc. 2000;131:463-7.

14. Kariwa H, Fujii N, Takashima I. Inactivation of SARS coronavirus by means of povidone-iodine, physical conditions, and chemical reagents. Jpn J Vet Res. 2004;52:105-12.

15. Samaranayake LP, Reid J, Evans D. The efficacy of rubber dam isolation in reducing atmospheric bacterial contamination. ASDC J Dent Child. 1989;56(6):442-444.

16. Kohn WG, Collins AS, Cleveland JL, Harte JA, Eklund KJ, Malvitz DM. Guidelines for infection control in dental healthcare settings-2003.

17. https://www.health.gov.au/sites/default/files/documents/2020/03/environmental-cleaning-anddisinfection-principles-for-covid-19.pdf [Last accessed on 07 May 2020].

18. http://www.indiaenvironmentportal.org.in/content/453336/the-bio-medical-wastemanagementamendment-rules-2018/ [Last accessed on 07 May 2020].

19. https://www.ada.org/ /media/CPS/Files/COVID/ADA_Int_Guidance_Mgmt_EmergUrg_Dental_COVID19.pdf [Last accessed on 07 May 2020].

20. Tim Smith, Jennifer Bushek, Tony Prosser. COVID-19 Drug Therapy- Clinical Drug Information. 2020.

21. Jahangir MA, Muheem A, Rizvi MF. Coronavirus (COVID-19): History, Current Knowledge and Pipeline Medications. Int J Pharm Pharmacol. 2020;4:140.

22. https://www.nih.gov/news-events/news-releases/nih-clinical-trial-investigational-vaccine-covid-19begins [Last accessed on 07 May 2020].

23. Martines, Jamie. Pittsburgh scientists, develop possible coronavirus vaccine, hope FDA can fast-track it. Pittsburgh Tribune-Review. 2020.

24. Kim E, Erdos G, Huang S, Kenniston TW, Balmert SC, Carey CD, et al. Microneedle array delivered recombinant coronavirus vaccines: Immunogenicity and rapid translational development. EBioMedicine. 2020:102743.

25. Hierholzer JC, Kabara JJ. In vitro effects of monolaurin compounds on enveloped RNA and DNA viruses. J Food Safety. 1982;4(1):1-12.

26. https://www.msn.com/en-ph/news/technology/dost-to-study-benefits-of-virgin-coconut-oil-on-covid19-patients/ar-BB12151z [Last accessed on 07 May 2020].

27. Raymond C, Tzi BN, Wei-Zen S. Lactoferrin as potential preventative and treatment for COVID-19. 2020.

28. Zhang R, Wang X, Ni L, Di X, Ma B, Niu S, et al. COVID-19: Melatonin as a potential adjuvant treatment. Life Sci. 2020;250:117583.

Hegde MN | Volume 1; Issue 1 (2020) | JDHOR-1(1)-003 | Review Article 